\title{
PRIMING HOST CITY PHYSICAL LEGACY PLANS: THE BIDDING CHRONICLES OF BRAZIL'S DERAILED SPORTING EVENT INFRASTRUCTURE PROJECTS
}

\author{
SETH I. KIRBY* AND LAUREN A. H. CRABB† \\ *Lord Ashcroft International Business School, Anglia Ruskin University, Cambridge, UK \\ $\dagger$ Department of Management and Human Resources, Coventry University London, London, UK
}

\begin{abstract}
This article presents a case study of the 2014 FIFA World Cup in Brazil and the 2016 Olympic Games in Rio de Janeiro to explore infrastructure development and physical legacies connected to the planning, bidding, and staging of mega-sporting events. Primary data were collected in Cuiabá in two phases during the 2014 World Cup and after the event in 2015. This entailed participant observation, structured observation, document analysis, and 15 semistructured interviews with the local population, as well as current and former government and stadium employees. Following the Rio 2016 Olympic Games primary data were collected from Porto Maravilha, Rio de Janeiro. In January 2018, 15 semistructured interviews were undertaken with tour operators and cultural businesses. Significant evidence indicates the ineffectiveness of urban and rural infrastructure development and facility improvements, delays and cancellations in infrastructure programs, stadiums and venues overshooting their original costs and budgetary requirements, and controversial targeted transport interventions. Practical managerial recommendations and strategies are offered to aid the implementation, management, and maintenance of host city infrastructure during the planning, bidding, hosting, and post-sporting event phases.
\end{abstract}

Key words: Mega-sport event (MSE); Infrastructure; Legacy; Event planning and policy; Brazil 2014; Rio 2016; Cuiabá; Porto Maravilha

Introduction

Over recent years, "Global South" cities and nations have increased their bidding activities in an attempt to compete to host a range of mega-sporting events (Haferburg \& Steinbrink, 2017; Maharaj, 2015). The primary justifications for wishing to stage these global events is that they can function as tools for progressing and levering major economic revenue streams, reshaping infrastructure, 
exploiting tourism demand, and expanding urban upgrade projects throughout the host city or nation (Gratton \& Preuss, 2008; Jones, 2001; Müller, 2012; Thornley, 2002). Successful bids have been tabled by the emerging markets of Brazil, Russia, and South Africa, who have intentionally pursued strategies to fast track infrastructure construction programs that address a lack of basic physical structures and sporting facilities (Gaffney, 2015; Haferburg \& Steinbrink, 2017; Müller, 2012; Silvestre, 2016).

Although frameworks to test and measure legacies have been discussed, particularly in academic circles (e.g., Dickson, Benson \& Blackman, 2011; Kassens-Noor, Wilson, Müller, Maharaj \& Huntoon, 2015), we argue these evaluations tend to fall short politically due to the lengthy period of time needed to evaluate the success of sporting event legacies (Carlsen \& Taylor, 2003). Tensions are prevalent between these evaluation processes and the political justification for short-term legacy results. Coakley and Souza (2013) suggested event legacies are envisaged, debated, and created in the political actions of the bid preparation. We align with this notion and use the preevent phase as our focus for this short-term legacy assessment.

This article tracks the infrastructure impacts and legacy of two mega-sporting events (MSEs) in Brazil within a 2-year period. Brazil hosted the 2014 FIFA Football World Cup and the Rio 2016 Olympic Games, a feat not previously achieved by any other country ( $\mathrm{Li}, 2013)$, and therefore offers an opportunity to analyze the two events within the context of the same country. In doing so, the article makes two contributions to the literature. First, our article responds to calls for examinations on the Global South MSE experience (Maharaj, 2015). Second, we contribute to knowledge surrounding how the preevent forces are enacted in the "glocal" production of sporting infrastructure, and how that influences the postevent infrastructure legacy (Horne, 2011; Thomson, Schlenker, \& Schulenkorf, 2013). The article unfolds as followed: in the next section, we begin by reviewing the literature on preevent, bidding, and planning ambitions in a number of MSE locations. Infrastructure, venue development, and budgetary management are outlined and assessed in relation to recent men's FIFA football World Cups and Olympic Games.
Following this, we present our case studies and discuss the results pertaining to preevent evaluations and postevent legacies. Finally, managerial implications, practical recommendations, and further research directions are proposed.

\section{Hosting Mega-Sporting Events: Budgets, Infrastructure, and Urban Development}

Cities, regions, and nations have long been drawn to hosting MSEs for their plethora of positive social and economic benefits. However, there is now a growing literature that warns that some hosts have experienced negative socioeconomic outcomes (Preuss, 2007, 2015). For example, initial costs and budgets for a host city or region can be hopeful and linked to economic predictions that are frequently overstated, resulting in a failure to materialize long-term tangible benefits (Cashman $\&$ Horne, 2013; Preuss, 2009). The funding of these projects often culminates in hosting regions accepting enormous debts connected to infrastructure development and maintenance (Thomson et al., 2013). Li (2013) separated the infrastructure requirements for large-scale sporting events into two categories. Firstly, specific infrastructure established primarily for the event (e.g., stadia and accommodation for athletes). Moreover, the second category accounted for infrastructure essential for hosting the event, such as transportation systems (Li, 2013; Searle, 2012). Cabral and Silva (2013) extended this to include the use of ancillary facilities, which they emphasized to incorporate museums and convention centers located nearby stadiums. Preuss (2009) argued it is often these ancillary facilities that form a positive legacy, although the future operational costs are largely underestimated (Mills \& Rosentraub, 2013).

Substantial budgets and resources are needed to develop the appropriate sporting, transport, and ancillary infrastructure, which commonly leads to a reliance on public expenditure and subsidies from taxpayers (Gratton \& Preuss, 2008; Mills \& Rosentraub, 2013; Preuss \& Schnitzer, 2015). These funds can be diverted from social and environmental programs to the development of sporting infrastructure (Cabral \& Silva, 2013; Jones, 2001; Li, 2013; Preuss, 2009). In turn, most large-scale facility and venue constructions are justified on the basis of 
their prospective benefit to the economy and local participation levels postevent (Gaffney, 2015). Searle (2002) noted that this relocation of spending and resources could have negative impacts on urban development in other areas of the city or region. Hence, understanding locals' perceptions in preevent periods, engaging the host community in the decision-making processes, and securing locals' MSE support are seen as critical success attributes (Michopoulou \& Giuliano, 2018; Pappas, 2018; Ritchie, 2000). For example, in response to accusations of facilities becoming "white elephants" after the event, where the stadia are underused, some structures are designed to be dismantled after the event or reduced in capacity (Gratton \& Preuss, 2008; Li, 2013; Müller, 2012; Thornley, 2002).

\section{Towards Theorizing the Importance of Preevent Evaluation for Legacy}

In the MSE lifecycle-bidding, planning and preparation, event delivery and postevent wrap up, and handover (Hiller, 1998; Kirby, Duignan, \& McGillivray, 2018) - legacy is broadly accepted as occurring in the postevent stage and incorporates the events context, temporal nature of planning, and positive and negative aspects that form in the hosting region (Preuss, 2007, 2015; Thomson et al., 2013). The above studies, like most examinations on legacies, predominantly focus on the immediate postevent outcomes. Coakley and Souza (2013) suggested rather than measuring the legacy outcomes at the postevent stage, there is room to evaluate the processes in the preevent stage and identify the factors that may detract favorable legacy outputs. To understand how legacies are formed, it is important to recognize the actors who have power to influence the development of legacy plans. In his evaluation of Brazil, India, and South Africa, Maharaj (2015) found the public had little or no consultation as costs escalated and the poorest became increasingly adversely constrained by the MSEs. He recognized the relationship between the private and public sector controlling the flow of capital and direction of activities during the planning and construction phases. On the other hand, Nunkoo, Ribeiro, Sunnassee, and Gursoy (2018) developed a theoretical framework associated with public trust in institutions organizing mega-sporting events. They posit corruption, transparency, and knowledge as influential dimensions upon the levels of public trust, and retaining or restoring this trust requires multiple stakeholder engagement and political will. Furthermore, the authors establish that public trust should form an integral part of any future bid package, but to date, organizers have failed to appreciate such elements. Other researchers such as Henne (2015) argued that little is known about the consequences of transparency and corruption linked to MSEs, and empirical infrastructure analysis is scant within MSE studies ( $\mathrm{Li}, 2013)$. Therefore, we address this gap by analyzing the impact of preevent organization on the legacy of two events. Specifically, we focus on two host territories: Cuiabá (Brazil 2014 FIFA World Cup) and Porto Maravilha, Rio de Janeiro (Rio 2016 Olympic Games).

\section{Brazilian Political and Policy Environment}

Brazil is unique in the social and political context in which the two mega-sporting events, Brazil 2014 and Rio 2016, took place. Politics is closely aligned to functioning components of society within Brazil; military dictatorship is still in living memory, and senior political officials are involved in ongoing national corruption investigations, which led to the 2015 impeachment of President Dilma and imprisonment of former President Lula (Cowie, 2018). This is set against the backdrop of over 1 million people taking to the streets in 2013 to protest against hosting the 2014 World Cup (Watts, 2013). In Rio, there were similar anti-Olympic Games street marches and protests. Ultimately, the public was voicing their concerns on public spending for event infrastructure (e.g., stadiums) when health and education needed to take priority. Although a country at peace, Brazil's internal politics and social divisions are stark (Korstanje, Tzanelli, \& Clayton, 2014), therefore offering a contested terrain in which politics played a significant role in the planning, running, and evaluation of the two MSEs.

In recent times, comparable to the internal political implosion in Brazil, the International Olympic Committee (IOC) and Fédération Internationale de Football Association (FIFA) have come under increased scrutiny over costly host outlays and the lack of transparency in how these "regimes" 
award bidding contracts to host cities. In particular, FIFA have struggled to cope with corruption scandals, facing a public backlash and garnering attention from the press that has ensured that their problematic reputation remains a continual issue (Horne \& Silvestre, 2016). Both the IOC and FIFA have tried to counteract these claims by aligning themselves with the global discourse on sustainable development, declaring their flagship events are socially and environmentally beneficial (Hayes \& Karamichas, 2012).

The politics within the government and arrangements with international organizing bodies were fundamental to the special political circumstances that the article discusses. This article takes a chronological perspective and charts how Cuiabá and Rio de Janeiro were selected for, prepared, and hosted these events. As such, we have proposed a conceptual framework to visualize the creation and development of planned infrastructure goals (see Fig. 1). The "Host Event Project Planning for Infrastructure" (HEEPI) Nexus presents and delineates the planning processes enlisted throughout the bidding protocols of the two Brazilian MSEs. A number of planning dimensions must be prioritized for the hosting of the event to go ahead. For instance, constructing venues, upgrading facilities, and/or delivering stadia renovations. Simultaneously, a range of factors act as an external force on the operations of the MSE. This includes the host city or region's physical location, the current economic outlook, and the extent to which politicians possess a final say in key event decisions. A constellation of external contingent actors impart and influence the trajectory of the MSE with their divergent perspectives (e.g., public authorities or state-run departments). Other agreements like the host city contract (HCC) are activated between the private sport's governing body (e.g., IOC) and local host city. Additionally, the representation of the host region is mediated through their involvement with prominent international corporations and global press outlets.

\section{Method}

The study is informed by empirical data collected by the two researchers from the most recent mega-sporting events held in Brazil-the 2014 FIFA World Cup and Rio 2016 Olympic Games. We present case studies of the two cities, Cuiabá (World Cup) and Porto Maravilha, Rio de Janeiro (Olympic Games), to illustrate contextual similarities and differences in a bounded time scale, determined by the wider socioeconomic circumstances (Saunders, Lewis, \& Thornhill, 2009). It is acknowledged that the results from these cases cannot be generalized to all host cities, but reflect the types

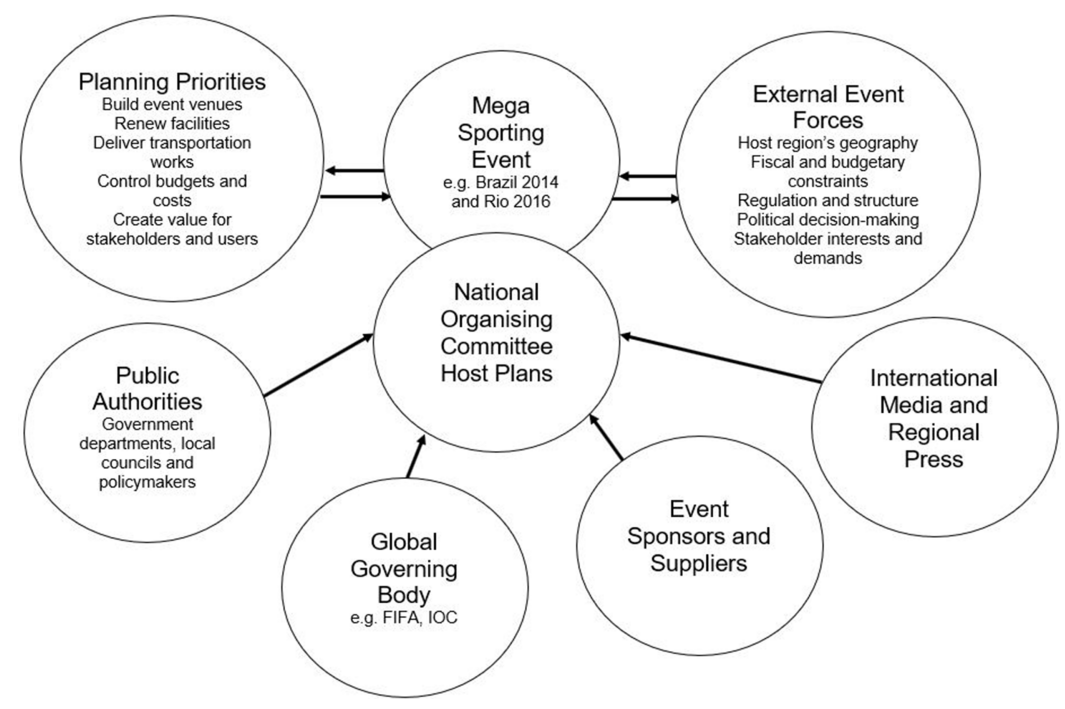

Figure 1. Host Event Project Planning for Infrastructure Nexus. 
of issues that host cities might encounter. Therefore, they are presented as standalone examples.

According to Yin (2018), there are four testing criteria for judging the quality of case study research design. These include construct validity, internal validity, external validity, and reliability. These tests for quality were applied throughout the collection of primary and secondary sources and triangulation was used to ensure the validity of sources. Validity in the primary data collection was maintained through the recruitment of a wide spectrum of state, corporate, and local community actors.

The second author collected data on the 2014 FIFA World Cup host city of Cuiabá, capital city of Mato Grosso. Eleven months of ethnographic fieldwork in Cuiabá was undertaken in two phases between 2014 and 2015. The first phase coincided with the World Cup tournament and focused on the preparation of the tournament, while the second phase in 2015 focused on the short-term infrastructure and legacy impacts. Fifteen semistructured interviews were held with the local population, current and former government, and stadium employees. Documentary analysis was conducted on mainstream press and social media reports, official government, FIFA documentation, and unofficial blogs of residents in Cuiabá. Structured observation of the stadium, airport, and light railway system line were undertaken in 2014 and 2015 and participant observation was used to support or challenge the various claims by actors. Triangulation was an essential aspect of data collection and analysis of data came from a multitude of sources (Atkinson, 2015).

The portion of the study conducted in Rio de Janeiro by the first researcher mirrored the 15 semistructured interviews conducted by the second researcher. Interviews were delivered with tourism and cultural organizations in January 2018 to uncover insights into the post-Rio 2016 Games physical infrastructure legacies. Over the course of a 3-week period, 1,700 photographs were obtained; this was supplemented by regular videos - nine individual online videos were created altogether. Approaches to ethnographic techniques generated knowledge and themes using visual data (photographs), web-based tools, and digital video recordings (e.g., vlogs) to represent the researchers' experience and issues relating to MSE infrastructure outcomes (Pink, 2013). Moreover, the first author undertook and analyzed a range of host city materials including official bidding plans, local authority, and nongovernmental organization (NGO) reports.

\section{Results and Discussion}

\section{Case Study: The 2014 World Cup Host City of Cuiabá}

Cuiabá, the capital of Mato Grosso, is situated in the center-west region of Brazil (Crabb, 2018). During the bid phase, Cuiabá was one of 18 Brazilian cities who bid to host the 2014 World Cup. In a FIFA inspection, Cuiabá was one of 6 cities thought to not have the appropriate infrastructure and therefore could not host the World Cup (FIFA, 2007). However, in 2009, Cuiabá was announced as a host city, a coup largely achieved through political maneuvering and use of personal networks of state-level elites, some of whom traveled to Switzerland to liaise with FIFA officials (Wilson, 2014). As a peripheral city, there was a consolidated infrastructure development program, including a new stadium (Arena Pantanal), to achieve international environmental certification and a new light railway system linking the stadium to key areas within the city. However, these two projects were beset with problems from the start.

\section{Arena Pantanal Construction and Delivery}

The initial bid package sent to FIFA was prepared by local architectural firm Castro Mello; they were also contracted by the Mato Grosso government to produce architectural drawings for the new stadium in the preparation phase. These drawings were never produced and before Cuiabá were declared as hosts, mismanagement had cost the tax payer $\mathrm{R} \$ 500,000$ (BRL R $\$$ ) or $£ 117,361$ (Bess, 2013). Cuiabá were given host city status in 2009, construction started in early 2010 but was temporarily suspended in November 2010 after Mato Grosso state auditors prevented funding from the state government due to irregularities with the budget (Tavares, 2011). In addition, the preparation phase was also tarnished by the change of seat supplier. The contract to supply the seats was won in July 2013 by a Cuiabá-based company, Kango. They were 
to supply 44,500 seats at a cost of $\mathrm{R} \$ 19.4$ million $(£ 4,553,608)$. An investigation by the civil prosecution service advised the cancellation of the contract as they found Kango supplied the National Stadium in Brasilia at R\$175 (£39.14) each. As a result of this investigation Kango lost the contract to another company, Desk, who quoted the state government $\mathrm{R} \$ 150$ (£35.21) per seat. Due to inconsistencies related to another contract in Sao Paulo, the company was not permitted to hold a contract with a government-based enterprise for 5 years. At this point in 2013, the original company, Kango, had their contract reinstated after they offered their original contract at a $6 \%$ discount. A new contract was then conceived and Kango stated the seats would be installed by 2015 unless a premium was paid (Segalla, 2013).

Although the event delivery phase was successful, the postevent phase of the cycle has been controversial. Since the 2014 Brazil World Cup, the stadium has been chronically underused, primarily due to construction problems still not being resolved. The stadium was closed in January 2015 due to flooding caused by the wet season. By 2016 the official capacity of the stadium was reduced to 10,000 (Pablo, 2016). On the July 15, 2016, the Mato Grosso government blocked $\mathrm{R} \$ 28$ million $(£ 6,572,219)$ to the construction company Santa Barbara and Mendes Junior after they had not completed the agreed works (Pablo, 2016). In 2016, only R $\$ 100,000$ had been made from events with an average crowd of 766 for the local football team, compared to monthly maintenance costs of R $\$ 600,000$. In January 2017, a survey was undertaken to assess the main problems of the stadium. Findings of this survey revealed the sound system was not fully functioning, obvious flooding in the dressing rooms from the wet season, and homeless squatters occupying the restaurant areas (Rimoli, 2018). One resident summarized their feelings:

I am so sad when I look at the stadium, it could have been so beautiful, but corruption is everywhere. Welcome to Brazil, welcome to my city. (Interview 3)

\section{VLT Infrastructure Program}

The other main infrastructure project, the railway system (VLT), was contentious from the outset of the bid phase. When the original bid package was created in 2009, the state government intended to build a railway system in the city. After consultation they revised the plans and developed a bus expressway, costing $\mathrm{R} \$ 488.8$ million (£114,732,167). In 2011, a new state government traveled to Porto, Portugal and after witnessing their train system decided to reinstate the train plans at a cost of $\mathrm{R} \$ 1.477$ billion ( $£ 346,684,555)$. It was thought the VLT would promote Cuiabá as a modern city (Farinha, 2011). The former governor who endorsed the bus expressway gave his perspective on the change:

It was obvious to everyone the VLT was too expensive, we didn't need it. We needed more buses with more routes. The route of the VLT would not help the congestion in the down town area, that is why we chose the bus expressway. (Interview 7)

Cuiabá was the smallest 2014 Brazil Football World Cup host city and is suggested to have suffered the most extensive government infrastructure project intervention (Gaffney, 2015). The preparation phase was beset with problems and this resulted in the train system not being in place by the event delivery phase. The widened roads ready for the installation remained unfinished and large stretches of the road contained high fencing that was still visible throughout the tournament (see Fig. 2). A commuter reflected on the impact of the transport developments on her daily life:

I use the bus every day, but it takes so long. The buses are old, so the windows have to be open, but the fumes from the traffic jams make the air horrible. This VLT should have been finished months ago, but it's barely started. (Interview 12)

Works were still not concluded in the postevent phase. This is a consequence of contractual disputes and delays in the construction of the VLT system, which stopped in December 2014, and to date has yet to restart. In September 2016, the only actor bought to account for the corruption in the construction of the stadium and the VLT was the Governor during that period. Governor Silval Barbosa was responsible for signing off contracts and releasing funds. He was at the center of a corruption investigation in June 2014 where he was initially arrested but released on bail. As part of 

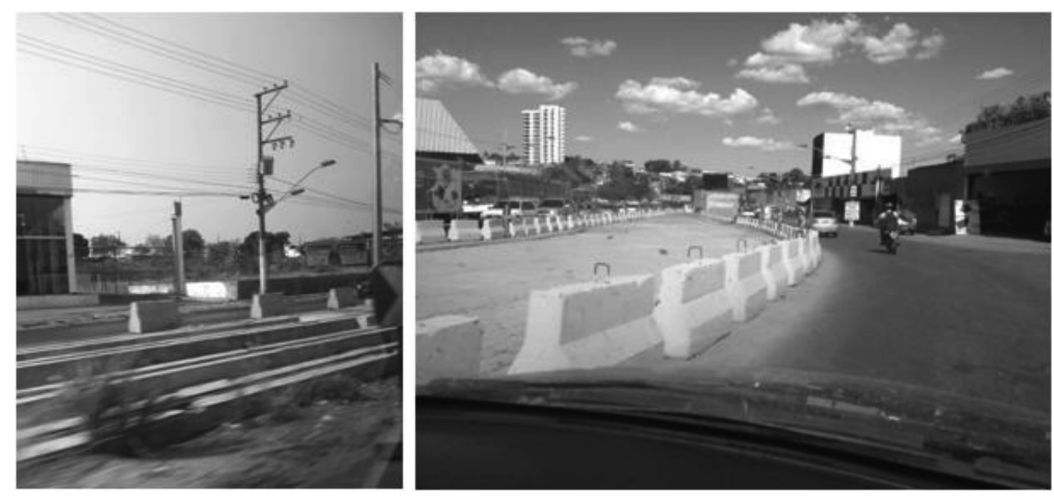

Figure 2. The VLT railway in Cuiabá, an unfinished infrastructure program associated with the 2014 World Cup (author's own photographs).

the police investigation "Sodom," Silval was later arrested again in September 2015. This investigation sought to uncover claims that the state government defrauded the federal government by falsely claiming grants. Barbosa is said to have endorsed 34 contracts as Governor of Mato Grosso, including RS1.4 billion $(£ 328,610,953)$ for the VLT, of which $\mathrm{R} \$ 500$ million $(£ 117,361,054)$ was said to be distributed to his colleagues (Ultimo Segundo, 2017).

\section{Case Study: Rio 2016 Olympic Games and Porto Maravilha's Urban Development Program}

Porto Maravilha was deployed through urban regeneration projects to remodel ambitious reforms of the old industrial and historic port (Carvalho, 2016: Guerra, Ferreira, \& Kipnis, 2018). The "Marvelous Port" revitalization of the harbor and downtown areas can be credited to the Eduardo Paes administration, who was the former mayor of the city from 2009 to 2017 (Carvalho, 2016). Urban development strategies amounted to infrastructure costs of $\mathrm{R} \$ 8$ billion covering an area of 5 million square meters (see Fig. 3), incorporating the docklands, VLT transport implementation, and the opening of new boulevards and squares (e.g., the Olympic Boulevard) (CDURP, 2016; Guerra et al., 2018; Rio de Janeiro City Government, 2014; Silvestre, 2016). In preparation for the Olympics, the revitalization of the port district was designated as one of the main legacies, and a neoliberal experiment to capture the city (Ribeiro
\& Santos Jr., 2017). Ancillary infrastructure was also planned, including the Rio Museum of Art (Museu de Arte do Rio-MAR) and the Museum of Tomorrow (Guerra et al., 2018). The Rio Museum of Art opened before the start of the 2014 World Cup in March 2013 and both museums are housed in the Mauá Square (Praça Mauá, see Fig. 3). The Museum of Tomorrow (Museu do Amanhã) is a lavish waterfront building erected at the Pier Mauá in late 2015, designed by lauded Spanish architect Santiago Calatrava (Carvalho, 2016; Sanchez \& Essex, 2017). At first glance, the museum is seen to project the values and practices of sustainability in its engineering and internal exhibitions, blending art and science, and enabling visitors to envisage an ecologically sound future (Watts, 2015). These developments enacted were perceived to be marginal to the 2016 Olympics, but they have become increasingly intertwined with the preparation of the Games (Carvalho, 2016). Additionally, construction companies and other corporate interests (e.g., office towers, hotels) played a major role in expediting Porto Maravilha's regeneration plans (Ribeiro \& Santos Jr., 2017; Silvestre, 2016).

\section{Ancillary Infrastructure, Facility Development, and Urban Spatial Transformation}

Reconfigurations catalysed by the Porto Maravilha project have changed the dynamics in the Pier Mauá plaza, as emphasized by a number of interviewees. One cultural organization exemplified that the land was: 


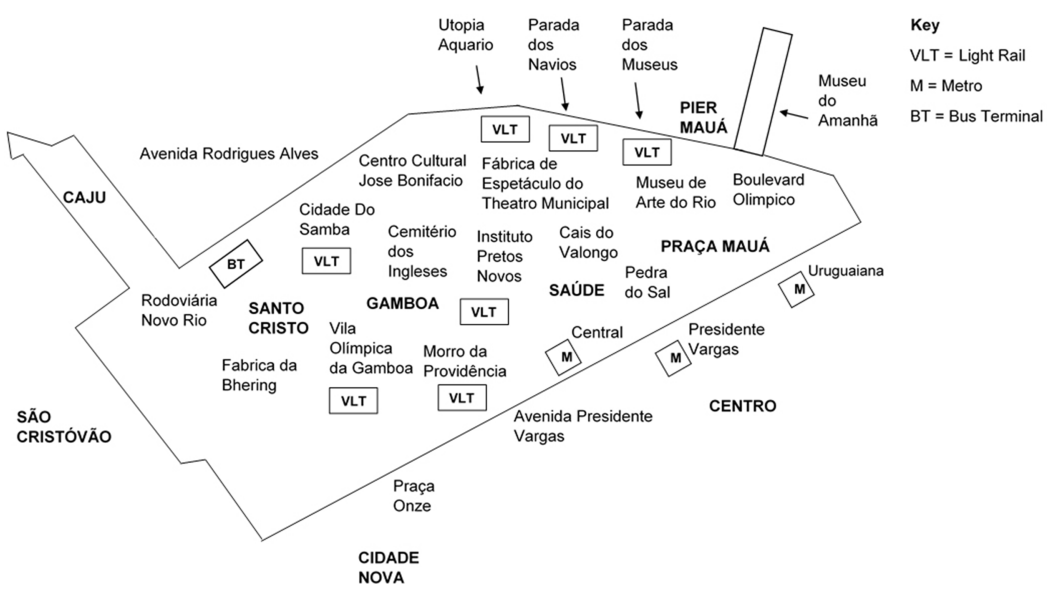

Figure 3. Overview of Porto Maravilha districts and urban infrastructure development zones (based on CDURP, 2016; RioOnWatch, 2016, and author's emphasis).

completely destroyed ... it was a bus parking lot ... nothing happened here before it was a dead zone... with this project, what happened is that you have a completely renovated area.

Although, these physical environmental changes could deter desirable outputs for the local, deprived populations and spark gentrification processes in the port area. One participant remarked that there was a

high social cost ... but it's more of an aesthetic thing, just a facade. It looks good but is it really good because we still have problems with health, and education and security.

In the media, misleading figures have circulated and been reported on concerning the costs of the construction of architectural installations and facilities in Porto Maravilha. Figures relating to the Museum of Tomorrow are disputed from $£ 40$ million or $\$ 59$ million (Watts, 2015) to claims from one interviewee of astronomical levels of R $\$ 245$ million. On the face of it, a range of hard infrastructure implementations did not satisfactorily meet local demand for facilities (Gratton \& Preuss, 2008; Li, 2013; Thornley, 2002).

Moving out from the main Porto Maravilha precinct, poor quality of facilities for the local community is evident. For example, this is reflected in the sad state of affairs of the Gamboa Olympic Village (Vila Olímpica da Gamboa, see Fig. 4). The

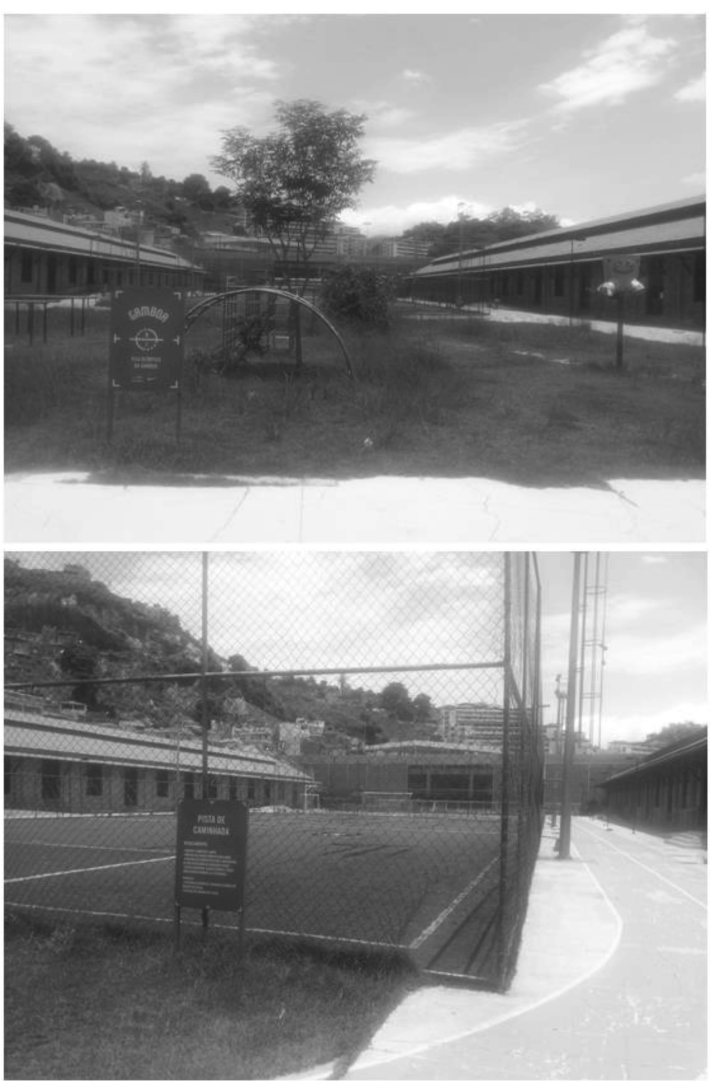

Figure 4. Gamboa Olympic village (author's own photographs). 
venue was inaugurated in 2004 as a recreation center and physical site designed to support sport and leisure activities (e.g., athletics, swimming, and skateboarding) for the local community in Gamboa. This perspective was emphasized by a local tour operator who reiterated the depressing sights of the facility:

This use to be setup as a skate park. You can see there was a track here for running and you can see the condition of this and a football installation ... they build it and leave, there's no maintenance, there's no budget to take care of this stuff. . . . This park use to be a really nice facility when they opened it. It's absolutely shocking!

The current situation of the infrastructure and recreation sites has demonstrated minimal preparation to feasibly maintain and upkeep the conditions of the facilities. In a number of instances, infrastructure and venues have been left redundant.

On the other hand, some would argue the outlook of the rejuvenated port is a clear improvement, recognizing all the physical structures that sprung up from this development and renovated "Olympic Boulevard" (Boulevard Olimpico). A cultural center spoke positively about the transformation of the port and the signals emanating from the residential market:

we are looking very optimistic about the Porto Maravilha project. But we know that takes time and it's important that the residential area of Porto Maravilha becomes a success.

However, in terms of real estate development and the corporate vacancy rate, a plethora of factors have influenced the current stock of retail and industrial office space in the port. Developing and retaining international corporations is a prevalent issue in Porto Maravilha. This is illustrated through the widespread empty and dilapidated corporate offices and towers littering the skyline (see Fig. 5).

Real-time analysis post-Games found that Rio de Janeiro's ex-Olympic event public spaces and dwellings have been designated to stage temporary events. A couple of the interviewees highlighted the central port area acting as a springboard and focal point as public space opportunities start to ripen for commercial event animation (Smith, 2018), including Praça Mauá and the Olympic Boulevard. One

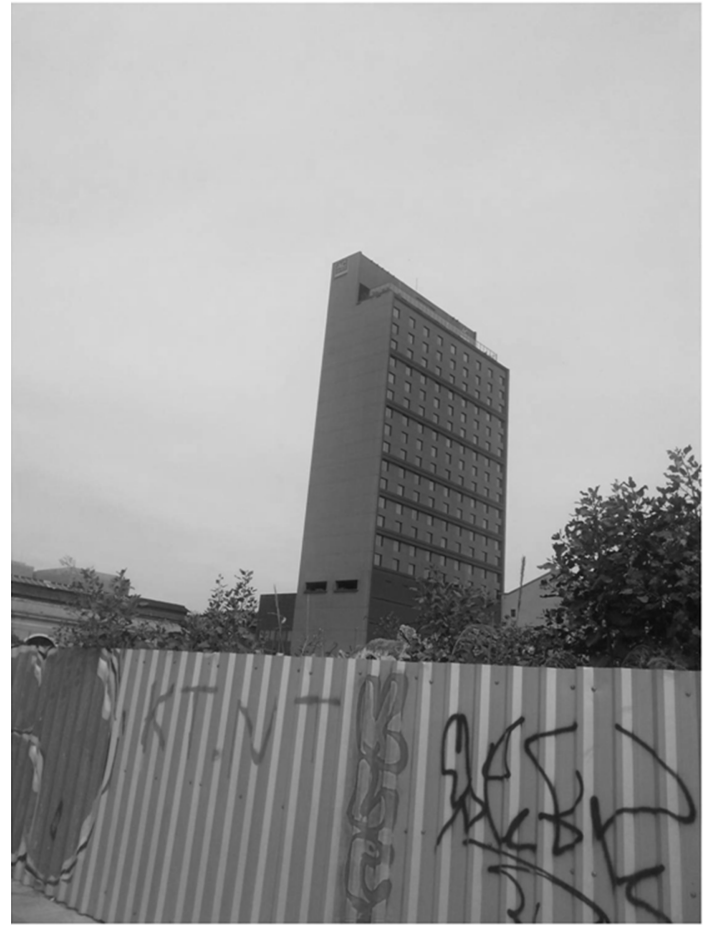

Figure 5. Empty corporate office building (author's own photograph).

participant stated these spaces are "areas that allow for these big events and shows." Spatial transformations in Praça Mauá have led to new initiatives such as pop-up markets. Another interviewee mentioned events developed in partnership with local cultural partners (e.g., museums) in the port zone, including the debut of the Rio de Janeiro Women of the World Festival (Festival Mulheres do Mundo, 2018). This festival is described as a celebration of the achievements of women and the inaugural edition landed in Rio in November 2018.

\section{Urban Transport Network: Targeted Removal or Inclusive Improvements?}

A sign of the planning and targeted interventions in Porto Maravilha is the implementation of the light rail vehicle (VLT). The government promise was to add substantial investment in transportation to connect routes stretching in and out of Porto Maravilha. Paes' ideas on the transit reforms were to link the transport networks - metro, buses, and airportsparticularly the $28 \mathrm{~km}$ light rail from Gamboa to 
Central to Santos Dumont terminal (Carvalho, 2016; CDURP, 2016). Key stations related to this study have been mapped and illustrated in Figure 3 . The controversy was evident surrounding which members of the local community the VLT served and the planned placement of the VLT tracks on streets. This assertion was highlighted by some participants, who claimed that:

it's not a means of transportation. It's not a means of transportation ... it's a means of changing the neighborhood, of valuing the neighborhood.

In this sense, problems in assembling the integrated transport system were the ongoing dilemmas faced by city planners, policymakers, and the local organizing committee. In some extreme cases for neighborhoods urban planning devices like the execution of the VLT have dogmatically reaped chaos upon citizens, leaving behind a homogenized, characterless ghost town - awaiting the next urban retail market pump. Accessibility and the temporary creation of transport systems for the local population was a highly questionable tactic pursued by the local authority.

Our analysis has presented multiple examples of infrastructure development as a consequence of hosting an MSE. Both cases demonstrated issues during the planning phase, which ultimately lead to deficient legacy outcomes for the cities under the spotlight. The time constraints between being awarded host city status and delivering finished infrastructure often invite complications for the local organizing committee and the state. For example, the seats in the Arena Pantanal were charged at a premium as the suppliers knew the constructors were working to a deadline. The seat suppliers were then able to profit at the expense of the taxpayer. A lack of transparency in the negotiation of contracts has had long term impacts. The final bill for taxpayers in Rio is still unclear as contradictory reports on the costs circulate. In Cuiabá, the difficulties surrounding negotiating contractual agreements meant the VLT was not completed and the governor was imprisoned.

These underlying issues in the preparation phase have led to more widespread ramifications for both host cities. There has been no funding set aside for maintenance of venues and facilities in Rio de Janeiro and there are office building blocks standing empty. In Cuiabá, the VLT still remains unfinished and the stadium is falling into disrepair. These case studies have shown how external actors have been able to influence the development of infrastructure projects. This includes the federal and state governments, sports organizing bodies, international corporations, and the local population. Each of these actors has their own agendas and has different abilities to influence outcomes; however, this is not static and can shift as priorities, funding, and time scale change. In Table 1, we have provided a detailed review of the parallels and disparities relating to planning and infrastructure impacts that emerged from the two host city destinations, Cuiabá and Porto Maravilha, Rio de Janeiro.

\section{Conclusions}

In this article, we intended to provide rich, empirical, and critical insights to establish the state of planned infrastructure development and returns post-mega-sporting event (MSE). The two case settings in question, Cuiabá and Porto Maravilha, illustrate how the infrastructure and urban legacies have been created and delivered in the short term. The review of the literature established what is not known in terms of the physical legacies. For example, the legacy of these infrastructure works attached to the events' bid preparation and delivery, and how this coexisted and operated within the confines of policy and decision making. In this regard, understanding the production of these legacies across the MSE lifecycle is pivotal. Particularly, how they are conceived across multiple locations, coupled with how key stakeholders seize upon the power to influence the eventual manifestation of legacy plans. Hence, MSE bidding and planning has been explored in order to make a judgement on the host cities' physical and spatial legacies.

A number of persistent issues have been stressed in relation to the hosting capacity of the city or nation (i.e., Brazil). For instance, the role and demands of "collective elites" (e.g., public authority and local organizing committee) in pushing through their local infrastructure agenda. In these examples, primary infrastructure as categorized by $\mathrm{Li}$ (2013) accounted for an extensive proportion of requirements (e.g., Cuiabá's Arena Pantanal). The 
Table 1

Host City Review of Planning and Infrastructure Impacts

Key Host City Themes

Budgets and costs

Infrastructure construction and transportation plans

Stadiums, venues, and ancillary facilities

Real estate development

Transparency and corruption
Cuiabá and Porto Maravilha Case Study Focus and Impact

Original costs have overrun their estimations. In Cuiabá, the bus expressway was initially expected to cost $\mathrm{R} \$ 488.8$ million $(£ 114,732,167)$ but this was replaced by the VLT at a staggering cost of R $\$ 1.477$ billion $(£ 346,684,555)$, funded by public finances.

The construction costs for Porto Maravilha's prodigious installations (e.g., Museum of Tomorrow) are contested and surpassed their projected budgets (Watts, 2015).

Unfinished infrastructure development program: The Arena Pantanal (Cuiabá) did not receive the planned international environmental accreditation as construction was not finished on time. Disputes between the state government and construction company led to $\mathrm{R} \$ 28$ million ( $£ 6,572,219)$ being withheld from the construction company.

Delayed and/or cancelled projects: Cuiabá's new light railway system (VLT) was not completed in time for the 2014 World Cup, due to a number of major construction delays and contractual disagreements. The Governor signed contracts worth RS1.4 billion $(£ 328,610,953)$ and the project remains unfinished at the time of writing.

Transportation faults: In Rio de Janeiro, implementing the VLT project contributed to widespread disruption and eroded access for local communities, especially in areas such as Gamboa. The controversy was also evident with regards to the location and routes of the VLT, and which communities the VLT served to benefit.

Stadia and venue usage: Due to the lack of strategic longer-term foresight in both cities, some venues and facilities remain underutilized. Although the Arena Pantanal's capacity was reduced after the 2014 World Cup, the stadium possesses many of the facets of a "white elephant."

Ancillary infrastructure and recreational facilities: The planning and integration of key ancillary facilities (e.g., the Rio Museum of Art and the Museum of Tomorrow) was poorly designed, coordinated, and ineffective in its execution. Moreover, the recreation center and site, Gamboa Olympic Village, has fallen into a dire state of disrepair and is therefore not able to fulfil its role in supporting local community sport and leisure activity.

Abandonment and unoccupied urban space: In the port region of Rio de Janeiro, empty buildings, abandoned office towers, and industrial space can be linked to the development of real estate. This has exacerbated corporate vacancy rates in Porto Maravilha when compared to other districts in the city.

Corruption scandals: The Governor in Mato Grosso was charged with misusing public funds-VLT expenditure contributed to this conviction. Substantial evidence in the two host cities points to how the political elites were the beneficiaries to the detriment of the local communities, commuters and the natural environment. importance of ancillary facilities encompassing museums and the extension of commercial buildings or units were more prominent in Rio de Janeiro-mainly due to the increased tourist numbers anticipated in the Porto Maravilha area. However, similarities can be drawn relating to the spiraling operational costs and budgetary management of both sites. In mega-sporting event-led planning and development, analysis of Cuiabá's and Porto Maravilha's urban projects highlights the lack of broader long-term thinking around how facilities are designed and organized. This includes visions for the positioning of ancillary infrastructure renovations, and dynamic interactions with urban "Live Site" public space regeneration (Smith, 2018), to new or upgraded urban transport systems. Across the board, host community involvement in the decision-making process was absent.

Applied to the context of the Global South, this examination delves into the critical relationship between MSE planning and urban infrastructure and renewal (Li, 2013). The cloud of uncertainty surrounding the degree to which infrastructure programs are seen to be unfinished and often 
terminated, grounding to halt at the various MSE phases is surely a missed opportunity for Brazil. Instead, hosting cities have become burdened by a political infliction that ignores citizen-led initiatives, in exchange for the pursuit of aesthetically homogenous, built-material city infrastructure.

Building upon the notions and distinctions of infrastructure costs and benefits to a host city or nation, this article explored how the evolving corruption saga serves to derail infrastructure projects and threatens the instability of the host city environment. State actors were seen to be engulfed in multiple corruption scandals, which have been identified and discussed in both city settings of Cuiabá and Rio de Janeiro. To limit and address these corruption concerns, MSE planning and bidding procedures must actively deal with issues of transparency. Global and pan-European bodies (e.g., FIFA, UEFA) have started to respond to these challenges posed to host cities. For instance, as part of the reformed 2026 FIFA Football World Cup bidding process, transparency is now listed as a key principle (FIFA, 2017). Likewise, within the planning and procedures of the 2024 Olympiad, the IOC has brought to the fore a number of anticorruption practices to combat fraudulent activity (IOC, 2017). Changes to regulatory structures could enable hosting cities to amend, retract, or veto certain event requirements if the stadiums and venues are thought to be unnecessary and usable. Furthermore, more incentives could be offered to hosting cities to develop temporary venues or replicate similar approaches devised for major sporting events, specifically the 2018 Gold Coast Commonwealth Games. In this instance, the organizers created a venues and services division responsible for the planning and delivery of temporary and permanent infrastructure services (Gold Coast 2018 XXI Commonwealth Games, 2017). Holistic and integrated sustainability policies and corporate social responsibility instruments may assist in coping with infrastructure resource frailties, such as facility size, as well as negating the possibilities of political figureheads benefiting from engaging in corruption and bribery as a consequence of planning and bidding to host an MSE.

This article made two contributions to the megasporting event literature. Firstly, it answered calls to further understand the "Global South" experience of
MSE hosting (Maharaj, 2015). This is particularly important as more developing countries are set to host MSE events in the future. With lower levels of public expenditure than their Global North counterparts, they are more susceptible to corporate sector exploitation. Secondly, we have contributed to the growing focus on preevent planning as the catalyst for transforming postevent outcomes. Here, it was found that the plethora of actors with different agendas and scope for influence attempt to assert their demands on the bidding and planning stages. This has been visualized in the "HEEPI" Nexus that was conceptualized earlier on in this article. Further research directions could explore the relationship between MSE facility developments, the expectations of locals, and achieving social outcomes. Longitudinal studies are necessary to tease out venue construction operational issues and evaluate the infrastructure decision-making processes of various relationships between government officials, policymakers, and building contractors. To this end, the study provides a critical event studies perspective and an in-depth picture of large-scale flagship development programs. Mechanisms and approaches for maintaining longer-term investments in the physical landscape have to be realistic and manageable, which considers local, host community participation and inclusion to ultimately derive benefits from heavy infrastructure and facility construction.

\section{References}

Atkinson, P. (2015). For ethnography. London, UK: SAGE. Bess, E. (2013). Projeto da Arena foi decisivo para Cuiabá ser cidade-sede, rebate ex-secretário Yuri. Retrieved from http://www.hipernoticias.com.br/copa-pantanal/ projeto-da-arena-foi-decisivo-para-cuiaba-ser-cidadesede-rebate-ex-secretario-yuri/28532

Cabral, S., \& Silva, A. F. (2013). An approach for evaluating the risk management role of governments in publicprivate partnerships for mega-event stadiums. European Sport Management Quarterly, 13(4), 472-490.

Callejas, I. J. A., de Oliveira, A. S., Santos, F. M. D., Durante, L. C., Nogueira, M. C. D. J. A., \& Zeilhofer, P. (2011). Relationship between land use/cover and surface temperatures in the urban agglomeration of Cuiabá-Várzea Grande, Central Brazil. Journal of Applied Remote Sensing, 5(1), 1-15.

Carlsen, J., \& Taylor, A. (2003). Mega-events and urban renewal: The case of the Manchester 2002 Commonwealth Games. Event Management, 8(1), 15-22.

Carvalho, B. (2016). Introduction: Rio, city of epithets: Olympic urbanism in context. In B. Carvalho, M. 
Cavalcanti, \& V. R. Venuturupalli (Eds.), Occupy all streets: Olympic urbanism and contested futures in Rio de Janeiro (pp. 20-29). New York, NY: Terreform.

Cashman R., \& Horne J. (2013). Managing legacy. In S. Frawley \& D. Adair (Eds.), Managing the Olympics (pp. 50-65). Basingstoke, UK: Palgrave Macmillan.

CDURP. (2016). Urban operation: Porto Maravilha. Retrieved from http://www.portomaravilha.com.br/ conteudo/imprensa/livreto_geral_INGLES_2016.pdf

Coakley, J., \& Souza, D. L. (2013). Sport mega-events: Can legacies and development be equitable and sustainable? Motriz: Revista de Educação Física, 19(3), 580-589.

Cowie, S. (2018). Lula begins prison sentence in Brazil after giving himself up to police. Retrieved from https://www. theguardian.com/world/2018/apr/07/crowds-in-saopaulo-block-lula-from-handing-himself-in

Crabb, L. A. H. (2018). Debating the success of carbon-offsetting projects at sports mega-events. A case from the 2014 FIFA World Cup. Journal of Sustainable Forestry, 37(2), 178-196.

Dickson, T. J., Benson, A. M., \& Blackman, D. A. (2011). Developing a framework for evaluating Olympic and Paralympic legacies. Journal of Sport and Tourism, 16(4), 285-302.

Farinha, R. (2011). Agecopa muda foco e deve optar por VLT; anúncio sai em 20 dias. Retrieved from http:// www.rdnews.com.br/executivo/agecopa-muda-foco-edeve-optar-por-vlt-anuncio-sai-em-20-dias/27553

Festival Mulheres do Mundo. (2018). Women of the World Festival Rio de Janeiro. Retrieved from http://www. festivalmulheresdomundo.com.br/en/festival

FIFA. (2007). Brazil bid: Inspection report for the 2014 FIFA World Cup. Retrieved from http://www.fifa. $\mathrm{com} / \mathrm{mm} /$ document/affederation/mission/62/24/78/ inspectionreport_e_24841.pdf

FIFA. (2017). Guide to the bidding process for the 2026 FIFA World Cup. Retrieved from http://resources.fifa.com/ $\mathrm{mm} /$ document/affederation/administration/02/91/88/61/ en_guidetothebiddingprocessforthe2026fifaworldcup_ neutral.pdf

Gaffney, C. (2015). The urban impacts of the 2014 World Cup in Brazil. In R. Gruneau \& J. Horne (Eds.), Mega-events and globalization: Capital and spectacle in a changing world order (pp.167-185). London, UK: Routledge.

Gold Coast 2018 XXI Commonwealth Games. (2017). Annual report 2016-2017. Retrieved from https:// gc2018.com/sites/default/files/2017-12/GOLDOC\%20 Annual\%20Report\%202016-17\%20incl\%20Financial $\% 20$ Statements_update $\% 2017$ NOV2017.pdf

Gratton, C., \& Preuss, H. (2008). Maximizing Olympic impacts by building up legacies. International Journal of the History of Sport, 25(14), 1922-1938.

Guerra, D., Ferreira, J., \& Kipnis, E. (2018). Towards cultural centrality in mega-event urban legacy: The case of Porto Maravilha and the Rio 2016 Olympic Games. In I. Brittain, J. Bocarro, T. Byers, \& K. Swart (Eds.), Legacies and mega events: Fact or fairy tales? (pp. 223-233). London, UK: Routledge.
Haferburg, C., \& Steinbrink, M. (2017). Mega Events in emerging nations and the festivalisation of the urban backstage. The cases of Brazil and South Africa. In J. Hannigan \& G. Richards (Eds.), The SAGE handbook of new urban studies (pp. 267-290). London, UK: SAGE.

Hayes, G., \& Karamichas, J. (2012). Olympic Games, megaevents and civil societies. Basingstoke, UK: Palgrave Macmillan.

Henne, K. (2015). Reforming global sport: Hybridity and the challenges of pursuing transparency. Law and Policy, 37(4), 324-349.

Hiller, H. H. (1998). Assessing the impact of mega-events: A linkage model. Current Issues in Tourism, 1(1), 47-57.

Horne, J. (2011). Architects, stadia and sport spectacles: Notes on the role of architects in the building of sport stadia and making of world-class cities. International Review for the Sociology of Sport, 46(2), 205-227.

Horne, J., \& Silvestre, G. (2016). Brazil, the Olympics and the FIFA World Cup. In A. Bairner, J. Kelly, \& J. Lee (Eds.), Routledge handbook of sport and politics (pp. 483-495). London, UK: Routledge.

International Olympic Committee. (2017). Host city contract principles: Games of the XXXIII Olympiad in 2024. Retrieved from https://stillmed.olympic.org/media/ Document\%20Library/OlympicOrg/Documents/HostCity-Elections/XXXIII-Olympiad-2024/Host-CityContract-2024-Principles.pdf

Jones, C. (2001). A level playing field? Sports stadium infrastructure and urban development in the United Kingdom. Environment and Planning A, 33(5), 845-861.

Kassens-Noor, E., Wilson, M., Müller, S., Maharaj, B., \& Huntoon, L. (2015). Towards a mega-event legacy framework. Leisure Studies, 34(6), 665-671.

Kirby, S. I., Duignan, M. B., \& McGillivray, D. (2018). Mega-sport events, micro and small business leveraging: Introducing the "MSE-MSB leverage model." Event Management, 22(6), 917-931.

Korstanje, M. E., Tzanelli, R., \& Clayton, A. (2014). Brazilian World Cup 2014: Terrorism, tourism, and social conflict. Event Management, 18(4), 487-491.

Li, S. (2013). Large sporting events and economic growth: Evidence from economic consequences of event infrastructure and venues. Event Management, 17(4), 425438.

Maharaj, B. (2015). The turn of the south? Social and economic impacts of mega-events in India, Brazil and South Africa. Local Economy, 30(8), 983-999.

Michopoulou, E., \& Giuliano, C. (2018). Understanding mega-events success and customer satisfaction. Event Management, 22(1), 9-23.

Mills, B. M., \& Rosentraub, M. S. (2013). Hosting megaevents: A guide to the evaluation of development effects in integrated metropolitan regions. Tourism Management, 34, 238-246.

Mobilize Brazil. (2014). Corredores Estruturais do VLT de Cuiabá. Retrieved from http://www.mobilize.org.br/ mapas/45/corredores-estruturais-do-vlt-de-cuiaba.html 
Müller, M. (2012). Popular perception of urban transformation through megaevents: Understanding support for the 2014 Winter Olympics in Sochi. Environment and Planning C: Government and Policy, 30(4), 693-711.

Nunkoo, R., Ribeiro, M. A., Sunnassee, V., \& Gursoy, D. (2018). Public trust in mega event planning institutions: The role of knowledge, transparency and corruption. Tourism Management, 66, 155-166.

Pablo, R. (2016). Construtora tem R\$28 mi bloqueados e é obrigada a concluir Arena Pantanal. Retrieved from http:// www1.folha.uol.com.br/esporte/2016/07/1792117-construtora-tem-r-28-mi-bloqueados-e-e-obrigada-a-concluir-arena-pantanal.shtml

Pappas, N. (2018). Pre-and postevaluation of residents' participation and support of the 2012 London Olympics. Event Management, 21(6), 747-770.

Pink, S. (2013). Doing visual ethnography (3rd ed.). Los Angeles, CA: SAGE.

Preuss, H. (2007). The conceptualisation and measurement of mega sport event legacies. Journal of Sport and Tourism, 12(3-4), 207-228.

Preuss, H. (2009). Opportunity costs and efficiency of investments in mega sport events. Journal of Policy Research in Tourism, Leisure and Events, 1(2), 131-140.

Preuss, H. (2015). A framework for identifying the legacies of a mega sport event. Leisure Studies, 34(6), 643-664.

Preuss, H., \& Schnitzer, M. (2015). Organization costs for a FIFA World Cup and their significance during a bid. Event Management, 19(1), 57-72.

Ribeiro, L. C. Q., \& Santos Jr., O. (2017). Neoliberalization and mega-events: The transition of Rio de Janeiro's hybrid urban order. Journal of Urban Affairs, 39(7), 909-923.

Rimoli, C. (2018). Por dentro de um elefante branco. Retrieved from https://esportes.r7.com/prisma/cosmerimoli/por-dentro-de-um-elefante-branco-abandonadoa-arena-pantanal-07022018

RioOnWatch. (2016). Port region residents suffer with ceaseless light rail construction. Retrieved from http:// www.rioonwatch.org/?p=33799

Rio de Janeiro City Government. (2014). Rio 2016-Olympic and legacy Retrieved from http://www.rio.rj.gov.br/ dlstatic/10112/4379008/4129850/RIO2016_estudos_ ING.pdf

Ritchie, J. R. B. (2000). Turning 16 days into 16 years through Olympic legacies. Event Management, 6(3), 155-165.

Saunders, M., Lewis, P., \& Thornhill, A. (2009). Research methods for business students (5th ed.). Harlow, UK: Pearson.

Sanchez, R. L. D. O., \& Essex, S. (2017). Architecture and urban design: The shaping of Rio 2016 Olympic legacies.
In A. Zimbalist (Ed.), Rio 2016: Olympic myths, hard realities (pp. 97-120). Washington, DC: Brookings Institution Press.

Searle, G. (2002). Uncertain legacy: Sydney's Olympic stadiums. European Planning Studies, 10(7), 845-860.

Searle, G. (2012). The long-term urban impacts of the Sydney Olympic Games. Australian Planner, 49(3), 195-202.

Segalla, V. (2013). MT contract is to receive $100 \%$ of the Pantanal Arena seats in 2015. Retrieved from https:// viniciussegalla.blogosfera.uol.com.br/2013/09/16/governo-de-mt-faz-contrato-para-receber-100-das-cadeirasda-arena-pantanal-so-em-2015/

Silvestre, G. (2016). Rio de Janeiro 2016. In J. R. Gold \& M. M. Gold (3rd ed.), Olympic cities: City agendas, planning and the world's Games, 1896-2020 (pp. 400-423). London, UK: Routledge.

Smith, A. (2018). Animation or denigration? Using urban public spaces as event venues. Event Management, 21(5), 609-619.

Tavares, M. (2011). Game on: Progress in Brazil's preparations for the 2014 FIFA World Cup. Retrieved from https:// sbri.innovateuk.org/documents/3272598/3753823/ Game+on+-+Progress+in+Brazil\%E2\%80\%99s+prepar ations + for + the $+2014+$ FIFA+World+Cup.pdf/d521ba7c4ebe-4aad-9879-c7c612595100

Thomson, A., Schlenker, K., \& Schulenkorf, N. (2013). Conceptualizing sport event legacy. Event Management, $17(2), 111-122$.

Thornley, A. (2002). Urban regeneration and sports stadia. European Planning Studies, 10(7), 813-818.

Ultimo Segundo. (2017). Ex-governador de MT entrega ao MPF vídeosdepoliticosrecebendopropina . Retrieved from http://ultimosegundo.ig.com.br/politica/2017-08-25/ silval-barbosa-propina-videos.html

Watts, J. (2013). Brazil's protests raise fears for World Cup as a million take to the streets. Retrieved from https:// www.theguardian.com/world/2013/jun/21/brazilprotests-football-world-cup

Watts, J. (2015). Museum of tomorrow: A captivating invitation to imagine a sustainable world. Retrieved from http:// www.theguardian.com/world/2015/dec/17/museum-oftomorrow-rio-de-janeiro-brazil-sustainability

Wilson, J. (2014). World Cup 2014: Rio horror show or a samba sensation? Retrieved from http://www.theguardian.com/football/2014/jun/07/world-cup-2014-riohorror-show-samba-sensation

Yin, R. K. (2018). Case study research and applications: Design and methods (6th ed.). Thousand Oaks, CA: SAGE. 